\title{
Massonia villosa (Hyacinthaceae), a new species from the Roggeveld, Northern Cape, South Africa
}

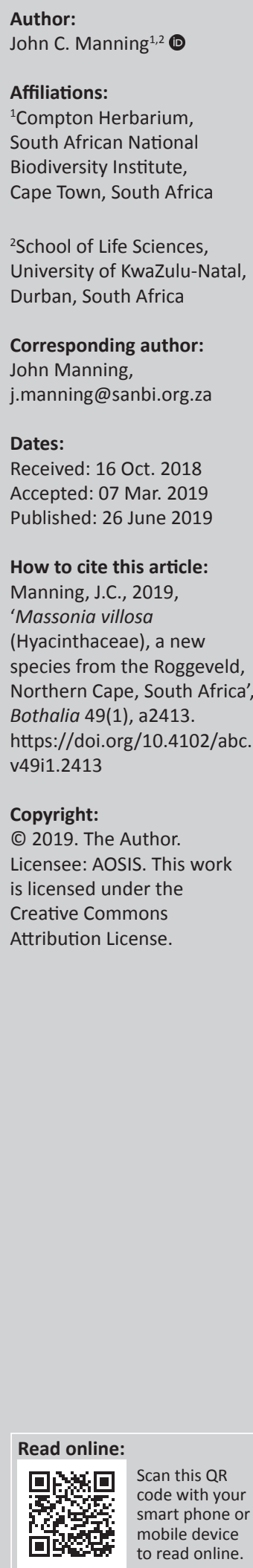

Background: Ongoing systematic studies in the African flora periodically reveal the existence of undescribed species.

Objectives: To describe the new species.

Method: Relevant literature was surveyed, and herbarium and fresh material were examined.

Results: Collections of a Massonia (Hyacinthaceae) from the escarpment near Sutherland in Northern Cape with unique, softly hairy foliage represent an undescribed species.

Conclusions: Massonia villosa J.C.Manning is a new species distinguished by the small, markedly convex leaves with recurved apex and pilose adaxial surface covered with soft, shaggy hairs up to $7 \mathrm{~mm}$ long and slender flowers without marked sigmoid coiling of the tepals.

Keywords: Hyacinthaceae; Massonia; new species; Scilloideae; southern Africa; taxonomy.

\section{Introduction}

Massonia Thunb. ex Houtt. (Hyacinthaceae subfamily Scilloideae tribe Massonieae; alternatively Asparagaceae subfamily Scilloideae tribe Hyacintheae) is one of several geophytic genera centred in the winter-rainfall region of southern Africa (Manning, Goldblatt \& Snijman 2002). Within the tribe, Massonia is characterised by a pair of spreading or prostrate, often variously pustulate or pubescent leaves, a capitate-corymbose or subspicate inflorescence with at least the lower bracts usually as long as or longer than the flowers, and firm-textured capsules that are exposed by the dry, withered perianth at maturity (Manning, Goldblatt \& Fay 2004). Molecular phylogenetic analyses consistently retrieve the genus as sister to Lachenalia J.Jacq. ex Murray (Buerki et al. 2012), which is distinguished from it primarily by its smaller floral bracts and often slightly zygomorphic flowers with biseriate stamens (Duncan 2012; Manning et al. 2004).

Some 30 species of Massonia are currently accepted (Manning 2019), although over 90 names have been published in the genus (Wetschnig et al. 2012). The account of Massonia by Baker (1897) for the Flora capensis is the most important of the early treatments of the genus and is in some ways superior to the later revision by Jessop (1976), who misunderstood several of the names and also circumscribed the species far too broadly. The inadequacy of his treatment was partially addressed by Müller-Doblies and Müller-Doblies (1997, 2010), who studied the winter-rainfall species extensively in the field. Since then the genus has been the subject of intensive field and particularly laboratory study (Martínez-Azorín et al. 2013, 2014a, 2014b, 2015a, 2015b, 2015c, 2018a, 2018b; Pinter et al. 2013, 2015; Wetschnig et al. 2012, 2014), leading to the description of a number of new species and the clarification of the application of the names of others. Most recently, the species from the core Cape Floristic Region (sensu Manning \& Goldblatt 2012) have been fully treated by Manning (2019) in the first modern regional treatment for the genus. Of the 14 species recorded by Manning (2019) from the core Cape Floristic Region, all but two are endemic or near-endemic to the region.

These accounts have gone a long way to improving our understanding of the genus Massonia, although additional species remain to be described from interior South Africa, particularly Namaqualand and the Upper Karoo (Manning 2019) in the Extra Cape Floristic Region (Snijman 2013). One of these species is represented by two collections and a sight record from the Roggeveld Escarpment and Klein Roggeveld near Sutherland in Northern Cape, South Africa. These populations are unique among the known species in their convex leaves with softly pilose adaxial surface and are described here as Massonia villosa J.C.Manning. 


\section{Materials and methods}

This work is based on field and herbarium studies in the Northern and Western Cape, South Africa. All relevant herbarium specimens in BOL, NBG, PRE and SAM (acronyms after Thiers 2018), the primary holdings of material from the region, were examined, as well as any relevant types, either specimens or electronic images. Descriptions and illustrations are based on fresh and herbarium material.

\section{Taxonomy}

Massonia villosa J.C.Manning, sp. nov. Type: South Africa, Northern Cape, Sutherland (3220): Komsberg, Gunsfontein Farm, (-DA), 27 May 2016, J. Manning 3584 (NBG, holo.; PRE, iso.).
Deciduous geophyte. Bulb subglobose to ovoid, $10 \mathrm{~mm}$ to $15 \mathrm{~mm}$ diam., usually deeply buried, outer tunics leathery, greyish to pale brown. Leaves 2, opposite, blades spreadingrecurved, broadly ovate to suborbicular, 12-20(-30) $\times$ 15-25 mm, concave with apex curved under, acute or obtuse, leathery, upper surface bright green, densely villous with soft, flexuous hairs mostly $5 \mathrm{~mm}-7 \mathrm{~mm}$ long but shorter (up to $2 \mathrm{~mm}$ long) along margins distally, and ciliate apically with short stiff bristles up to $0.5 \mathrm{~mm}$ long, subterranean sheathing base $30 \mathrm{~mm}$ - $50 \mathrm{~mm}$ long. Inflorescence a condensed, subcapitate raceme, few- to several-flowered [5-flowered to 10(15)-flowered], flowers protruding well above leaves; bracts narrowly oblanceolate or lanceolate to ovate, 15-20 $\times$ (2-)5-10 mm, acute to acuminate, margins entire or with a few scattered denticles; pedicels at anthesis $10 \mathrm{~mm}$ to $20 \mathrm{~mm}$ long.

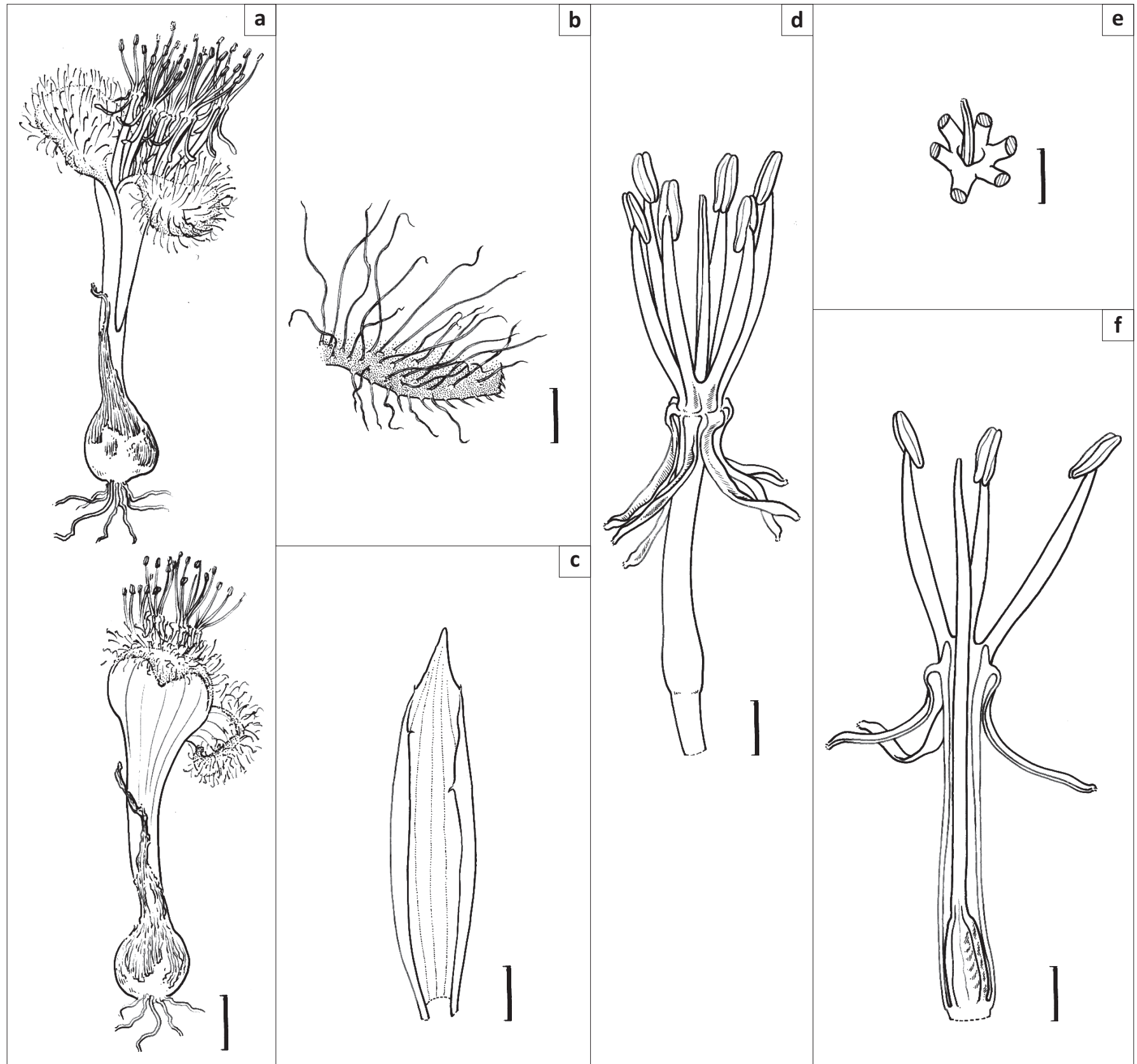

Source: Artist: John Manning

FIGURE 1: Massonia villosa. (a) flowering plants; (b) detail of leaf tip showing adaxial vestiture of long, flexous hairs and shorter bristles along apical margin; (c) bract; (d) flower; (e) mouth of staminal tube with protruding style; (f), half-flower showing gynoecium. Voucher: Northern Cape, Komsberg, Manning 3584 . Scale bar: (a) 10 mm; (b) 2 mm; (c-f) 3 mm. 
Flowers white, strongly lily-scented in evening; perianth tube narrowly cylindrical, 15-18 $\times 1.8-2.0 \mathrm{~mm}$; tepals arising \pm at same level, reflexed at base without sigmoid coiling, \pm incurving distally, linear, 7-10 × 0.8-1.0 mm, conduplicate, margins entire, apex penicillate. Filaments suberect, white, narrowly fusiform-filiform, $11 \mathrm{~mm}$ to $12 \mathrm{~mm}$ long, connate at base for $1.0 \mathrm{~mm}-1.5 \mathrm{~mm}$ in a longitudinally ribbed column not partially occluded at mouth by interstaminal gibbosities or invaginations; anthers $1.5 \mathrm{~mm}-2.0 \mathrm{~mm}$ long at anthesis, dull bluish grey with lilac or whitish pollen. Ovary oblongconical, pale yellow, $4 \mathrm{~mm}$ long, tapering and weakly contracted to style; style white, $21 \mathrm{~mm}-25 \mathrm{~mm}$ long, weakly differentiated from ovary, erect, slender. Capsules and seeds unknown. Flowering time: May to June (Figures 1 and 2).

Distribution and ecology: Endemic to the western interior escarpment around Sutherland in Northern Cape, South Africa, where it is known from two collections south of the town, one on the Komsberg and the other on the Klein Roggeveld, plus a sight record on the northern edge of the town (Figure 3); on seasonally moist, stony

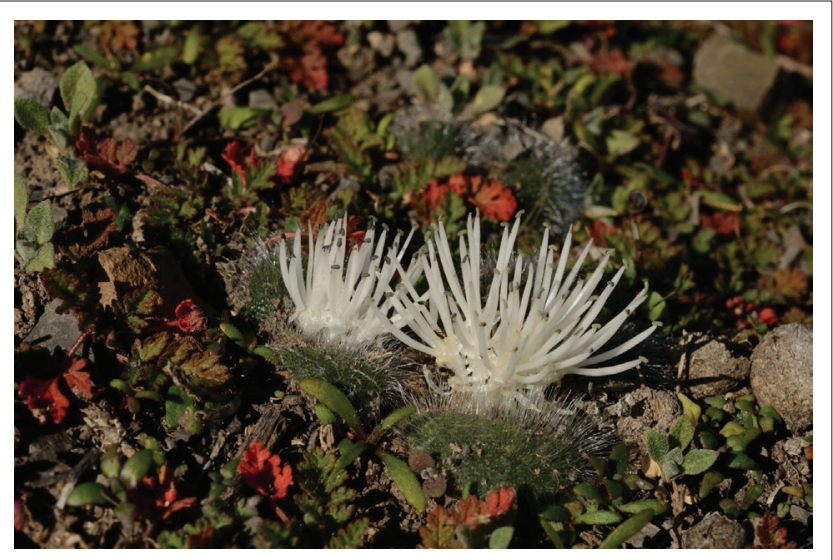

FIGURE 2: Massonia villosa in habitat, Northern Cape, Komsberg, Manning 3584.

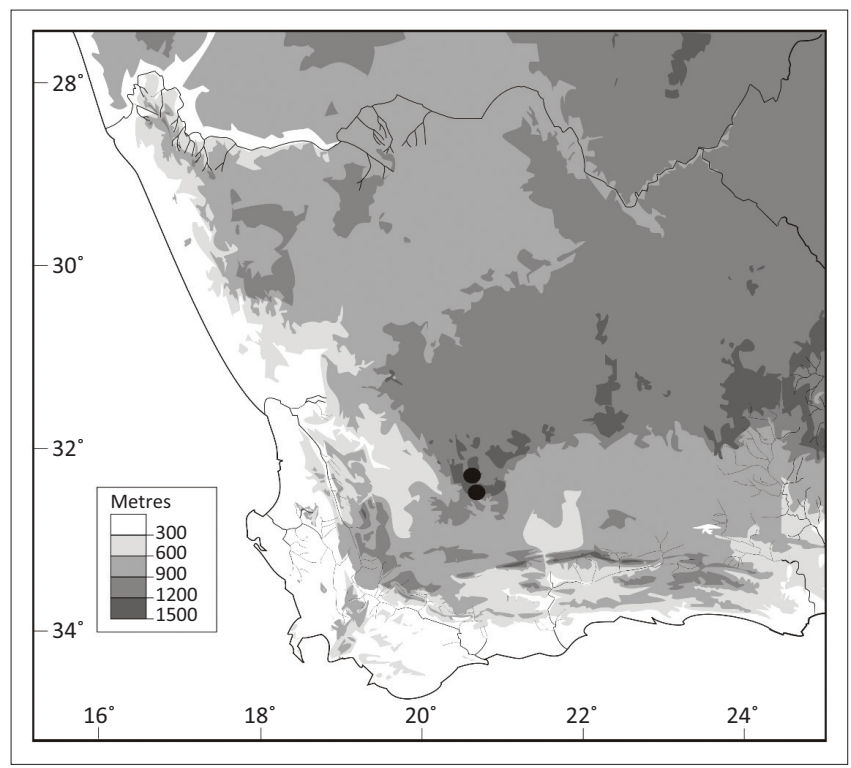

FIGURE 3: Distribution of Massonia villosa. Endemic to the western interio escarpment around Sutherland in Northern Cape, South Africa, where it is known from two collections south of the town, one on the Komsberg and the other on the Klein Roggeveld, plus a sight record on the northern edge of the town. clay slopes in renosterveld shrubland, at an altitude of $1200 \mathrm{~m}$ asl to $1600 \mathrm{~m}$ asl.

Diagnosis: Massonia villosa is unique in the genus in its small, markedly convex leaves with recurved apex and densely pilose upper surface closely covered with soft, shaggy hairs up to $7 \mathrm{~mm}$ long. The fragrant, white flowers have a slender perianth tube $15 \mathrm{~mm}-18 \mathrm{~mm}$ long, with strongly reflexed tepals with at most a slight sigmoid curvature but not coiled at the base, and the filaments are shortly connate at the base for $1.0 \mathrm{~mm}-1.5 \mathrm{~mm}$, without basal gibbosities or invaginations partly occluding the mouth of the tube. The anthers are dull bluish grey with paler pollen, and the ovary is weakly contracted at the apex into the slender style. The bulbs are typically deeply buried, with the subterranean sheathing base of the leaves much longer than the blade.

Relationships among the species in Massonia section Massonia (species with corymbose-capitate inflorescences) are still unclear (Manning 2019). A group of species including Massonia pseudoechinata Mart.-Azorín et al. has been identified on the basis of an obclavate gynoecium with the ovary tapering imperceptibly into the thickened base of the style and the often blue anthers (Martínez-Azorín et al. 2015c). This group includes another Roggeveld species, Massonia roggeveldensis Mart.-Azorín et al., which superficially resembles $M$. villosa in the slender, white perianth and tepals without sigmoid coiling, but differs from it in the characteristic obclavate gynoecium, filaments only very shortly connate at the base for up to $0.5 \mathrm{~mm}$, and most markedly in its plain, glabrous leaves.

Certainly, M. villosa cannot be confused with any known species of Massonia, none of which has even remotely similar foliar vestiture. In all other species known with pubescent foliage, the adaxial or upper surface of the leaves is at most echinate or setose, with stiff bristles up to $2 \mathrm{~mm}$ long.

Conservation notes: Massonia villosa is a local endemic known from three localities up to $50 \mathrm{~km}$ apart, although its true area of occupancy is not fully known. None of the localities lies within a formal conservation area and at least two of them are susceptible to habitat transformation: the population on the edge of the town of Sutherland by urban expansion as it lies on the periphery of the settlement, and the type locality on Gunsfontein Farm by farming practices as it lies almost within the farmyard itself.

\section{Additional material seen}

WESTERN CAPE. 3320 (Montagu): $2 \mathrm{~km}$ from turnoff on N1 towards Sutherland, (-BA), 14 Sep 2004 [past flowering], D. Snijman 1927 (NBG). Note: This locality is probably incorrect. I accompanied the collector, D. Snijman, to the site as indicated on the label, but she was unable to recognise it and suggested that it had been incorrectly transcribed and that the actual locality was in fact $2 \mathrm{~km}$ from the turnoff on the R354 towards Sutherland via Komsberg, placing it on the Klein Roggeveld (3220DC). 


\section{Acknowledgements}

Elizabeth Parker assisted with field work, Michelle Smith prepared the distribution map and Luvo Magoswana assisted with the electronic figure. Material was collected by permission from Northern Cape Nature Conservation.

\section{Competing interests}

The author declares that he has no financial or personal relationships that may have inappropriately influenced him in writing this article.

\section{Authors' contributions}

I declare that I am the sole author of this research article.

\section{Funding}

This research received no specific grant from any funding agency in the public, commercial, or not-for-profit sectors.

\section{Data availability statement}

Data sharing is not applicable to this article as no new data were created or analysed in this study.

\section{Disclaimer}

The views and opinions expressed in this article are those of the author and does not necessarily reflect the official policy or position of any affiliated agency of the author.

\section{References}

Baker, J.G., 1897, 'Liliaceae', in W.T. Thiselton-Dyer (ed.), Flora capensis, vol. 6, pp. 253-528, L. Reeve \& Co., Ashford, Kent.

Buerki, S., Jose, S., Yadav, S.R., Goldblatt, P., Manning, J.C. \& Forest, F., 2012, 'Contrasting biogeographic and diversification patterns in two Mediterranean-type ecosystems', PLoS One 7, 1-11. https://doi.org/10.1371/journal.pone.0039377

Duncan, G., 2012, The genus Lachenalia, Kew Publishing, Royal Botanic Gardens, Kew. Jessop, J.P., 1976, 'Studies in the bulbous Liliaceae in South Africa 6: Taxonomy of Massonia and allied genera', Journal of South African Botany 42, 404-437.

Manning, J.C., 2019, 'The genus Massonia Thunb. ex Houtt. (Hyacinthaceae: Scilloideae) in the Core Cape Region', South African Journal of Botany 121 329-354. https://doi.org/10.1016/j.sajb.2018.11.015

Manning, J.C. \& Goldblatt, P., 2012, Plants of the Greater Cape Floristic Region 1: The Core Cape Flora, Strelitzia 29, South African National Biodiversity Institute, Pretoria.
Manning, J.C., Goldblatt, P. \& Fay, M.F., 2004, 'A revised generic synopsis of Hyacinthaceae in sub-Saharan Africa, based on molecular evidence, including new combination and the new tribe Pseudoprospereae', Edinburgh Journal of Botany 60, 533-568.

Manning, J.C., Goldblatt, P. \& Snijman, D., 2002, The color encyclopedia of Cape Bulbs, Timber Press, Portland, OR.

Martínez-Azorín, M., Clark, V.R., Pinter, M., Dold, A.P., Crespo, M.B., Barker, N.P. et al., 2014a, 'Massonia dentata (Asparagaceae, Scilloideae), a new species from the Nuweveldberge, and typification of the Sneeuberg endemic M. calvata (southern Great Escarpment, South Africa)', Phytotaxa 175, 201-215. https://doi.org/ 10.11646/phytotaxa.175.4.2

Martínez-Azorín, M., Dold, A.P., Pinter, M., Slade, J.M., Crespo, M.B., Milkuhn, G. et al., 2015a, 'Massonia obermeyerae (Asparagaceae, Scilloideae), a new species from South Africa', Phytotaxa 205, 39-50. https://doi.org/10.11646/phytotaxa.205.1.3

Martínez-Azorín, M., Pinter, M., Crespo, M.B., Alonso-Vargas, M. \& Wetschnig, W. 2018a, 'Massonia visseriae (Asparagaceae, Scilloideae): Rediscovery of a neglected species of Neobakeria and its transfer to Massonia', Phytotaxa 334 70-74. https://doi.org/10.11646/phytotaxa.334.1.11

Martínez-Azorín, M., Pinter, M., Crespo, M.B., Alonso-Vargas, M. \& Wetschnig, W., 2018b, 'Massonia inaequalis (Asparagaceae, Scilloideae), a distinct new species from South Africa', Phytotaxa 343, 94-98. https://doi.org/10.11646/phytotaxa.343.1.10

Martínez-Azorín, M., Pinter, M., Crespo, M.B., Pfosser, M. \& Wetschnig, W., 2013, 'Massonia mimetica (Hyacinthaceae, Hyacinthoideae), a new remarkable species from South Africa', Stapfia 99, 187-197.

Martínez-Azorín, M., Pinter, M., Crespo, M.B., Slade, J., Deutsch, G. \& Wetschnig, W., 2015c, 'Clarification of Massonia echinata and some other frequently misunderstood Massonia species (Asparagaceae, Scilloideae), with the description of M. Pseudoechinata and M. roggeveldensis', Phytotaxa 239, 101-129. https:// doi.org/10.11646/phytotaxa.239.2.1

Martínez-Azorín, M., Pinter, M., Deutsch, G., Brudermann, A., Dold, A., Crespo, M.B. et al., 2014b, 'Massonia amoena (Asparagaceae, Scilloideae), a striking new species from the Eastern Cape, South Africa', Phytotaxa 181, 121-137. https://doi. org/10.11646/phytotaxa.181.3.1

Martínez-Azorín, M., Pinter, M. \& Wetschnig, W., 2015b, 'Desertia, a new genus in Massonieae (Asparagaceae, Scilloideae), including the description of Desert luteovirens and the taxonomic revisions of Whiteheadia and Namophila', Phytotaxa 221, 201-225. https://doi.org/10.11646/phytotaxa.221.3.1

Müller-Doblies, U. \& Müller-Doblies, D., 1997, 'A partial revision of the tribe Massonieae (Hyacinthaceae) 1. Survey, including three novelties from Namibia: A new genus, a second species in the monotypic Whiteheadia, and a new combination in Massonia', Feddes Repertorium 108, 49-96. https://doi.org/ 10.1002/fedr.19971080106

Müller-Doblies, U. \& Müller-Doblies, D., 2010, 'De LiliiflorisNotulae 8: Two new Massonia species (Hyacinthaceae) from South Africa', Feddes Repertorium 121, 127-132. https://doi.org/10.1002/fedr.201000022

Pinter, M., Brudermann, A., Crespo, M.B., Deutsch, G., Martínez-Azorín, M., MüllerDoblies, U. et al., 2013, 'Massonia citrina (Hyacinthaceae, Hyacinthoideae) A new species from the Western Cape Province (South Africa)', Phytotaxa 112, 50-56. https://doi.org/10.11646/phytotaxa.112.2.3

Pinter, M., Martínez-Azorín, M., Crespo, M.B. \& Wetschnig, W., 2015, 'Massonia bakeriana (Asparagaceae, Scilloidea), a new pustulate species from the Northern Cape Province (South Africa)', Phytotaxa 222, 51-60. https://doi.org/10.11646/ phytotaxa.222.1.5

Snijman, D.A., 2013, Plants of the Greater Cape Floristic Region 2: The Extra Cape Flora, Strelitzia 30, South African Biodiversity Institute, Pretoria.

Thiers, B., 2018, 'Index Herbariorum: A global directory of public herbaria and associated staff', New York Botanical Garden's virtual herbarium, viewed 10 October 2018, from http://sweetgum.nybg.org/ih.

Wetschnig, W., Brudermann, A., Knirsch, W., Pinter, M. \& Pfosser, M., 2012, 'Massonia pustulata Jacq. 1791 and M. Longipes Baker 1897 (Hyacinthaceae), two frequently misunderstood species - Or how M. Pustulata became depressed', Stapfia 97 210-221.

Wetschnig, W., Martínez-Azorín, M., Pinter, M., Brudermann, A., Deutsch, G., Crespo, M.B. et al., 2014, 'Massonia saniensis (Asparagaceae, Scilloideae), a new species M.B. et al., 2014, 'Massonia saniensis (Asparagaceae, Scilloideae), a new species
from Lesotho, southern Africa', Phytotaxa 173, 181-195. https://doi.org/ from Lesotho, southern Africa
$10.11646 /$ phytotaxa.173.3.1 